\title{
Why and how do firms reshore? A contingency-based conceptual framework
}

\author{
Amy V. Benstead ${ }^{1} \cdot$ Mark Stevenson $^{1} \cdot$ Linda C. Hendry $^{1}$
}

Received: 2 September 2016 / Revised: 25 May 2017 / Accepted: 16 June 2017 /Published online: 9 August 2017

(C) The Author(s) 2017. This article is an open access publication

\begin{abstract}
Much of the growing body of reshoring literature has focused on why firms reverse a prior location decision. While valuable, this work needs extending to how the decision to reshore is operationalised. Using a two-stage approach, this paper presents a conceptual framework that covers both why and how firms reshore. The framework also utilises contingency theory to identify the factors that influence these decisions. It is therefore claimed to be more comprehensive than others frameworks found in the literature. First, a systematic literature review deductively develops an initial framework. Second, a revised version of the framework is presented using evidence from a single, exemplar case of captive reshoring in the textiles industry. The case evidence identifies new factors and extends a typology of reshoring decisions proposed in the literature to more accurately reflect the dynamic, complex, and incremental nature of the onshore-offshore-reshore location and ownership decision.
\end{abstract}

Keywords Reshoring · Backshoring · Location decisions · Contingency theory $\cdot$ Case study

Amy V. Benstead

a.benstead@lancaster.ac.uk

Mark Stevenson

m.stevenson@lancaster.ac.uk

Linda C. Hendry

1.hendry@lancaster.ac.uk

1 Department of Management Science, Lancaster University Management School, Lancaster University, Lancaster, UK

\section{Introduction}

There is growing interest from researchers and practitioners in the phenomenon of reshoring, whereby previously offshored manufacturing and related activities are brought back to a domestic location (e.g. Gray et al. 2013; Fratocchi et al. 2014). Although a large body of literature exists on offshoring and global location decisions (e.g. Jahns et al. 2006; Schoenherr et al. 2008; Kedia and Mukherjee 2009; Platts and Song 2010; Holweg et al. 2011; Zorzini et al. 2014), reshoring is a distinctly different phenomenon that deserves specific attention. It involves revising or reversing a prior decision, i.e. returning to the original location (Gray et al. 2013) and may also involve a change of ownership, e.g. from an external overseas supplier to an in-house, domestic arrangement (Gray et al. 2013; Fratocchi et al. 2014).

Much of the existing body of reshoring literature has focused on why firms reshore (e.g. Kinkel and Maloca 2009; Pearce 2014; Zhai et al. 2016). Although this work is valuable, it arguably treats the reshoring decision as a discrete event - it typically focuses on a snapshot in time and on an ex-post analysis of what drove a firm to repatriate. It does not support a firm through the transition by providing a structure for the entire reshoring process. It has therefore been recognised that it is important to go further - by not only understanding why firms reshore but also how they can do so successfully (e.g. Fratocchi et al. 2014; Ancarani et al. 2015; Barbieri and Stentoft 2016; Wiesmann et al. 2017). Recent work has sought to consolidate what is known about why firms reshore (e.g. Ancarani et al. 2015; Fratocchi et al. 2016; Joubioux and Vanpoucke 2016; Srai and Ané 2016; Wiesmann et al. 2017), but a framework is now needed that encapsulates both why and how firms reverse a prior location decision.

Most of the literature on reshoring is thus far conceptual. Only a very limited number of empirical studies have been 
conducted, with the most prominent being survey-based (e.g. Kinkel 2012). While there are some recent case study examples (e.g. Martínez-Mora and Merino 2014; Ashby 2016), there is a need for more in-depth case work to further our understanding of the reshoring process (Stentoft et al. 2016a). Reshoring could refer to returning to a domestic sourcing arrangement or repatriating an in-house operation, i.e. captive reshoring. While both are considered reshoring, there are likely to be major differences in terms of the level of complexity, financial investment, time required, etc. With the exception of Kinkel (2014), most of the literature to date has focused on sourcing or neglected to distinguish between firms according to whether they are making captive or outsourced reshoring decisions.

This paper develops a conceptual framework that considers both why a firm may decide to reshore and how this decision can be operationalised or implemented. This is based on a two-stage approach: (i) deductive development of the conceptual framework based on a systematic literature review; and, (ii) the refinement or enhancement of the initial framework using case study evidence. As encouraged by Bals et al. (2016), a contingency-based perspective is adopted (e.g. Sousa and Voss 2008) as many of the factors that affect the reshoring process are likely to be context specific, e.g. industry or product related. The prior research used in stage (i) includes, for example, Fratocchi et al. (2016), who recently identified a broad range of factors that drive the reshoring decision but without differentiating between general and contingent factors.

The paper begins with the following research questions:

1. Why do firms reshore, and how can the decision to reshore be operationalised?

2. What contingency factors affect the decision to reshore and its implementation?

A single case study is presented of a textiles firm that has engaged in both captive offshoring and captive reshoring, as defined by Kinkel and Zanker (2013). This enables the case of captive reshoring, which is argued to be distinctly different to sourcing, to be studied in isolation. The textiles (and clothing) industry is highly competitive and characterised by its global supply chains, short product lifecycles, and typical high labour intensity (Teng and Jaramillo 2006; Dana et al. 2007). It has previously experienced extensive offshoring to lower wage economies (Bolisani and Scarso 1996; Bruce et al. 2004) and may therefore have significant reshoring potential, despite its labour intensity (Martínez-Mora and Merino 2014; Ashby 2016; Robinson and Hsieh 2016). Such single industry research has been encouraged by Stentoft et al. (2016a).

The remainder of this paper is organised as follows. Section 2 outlines the two-stage method before Section 3 reviews the reshoring literature to develop an initial conceptual framework. Section 4 presents the case study evidence, followed by a discussion in Section 5 where the framework is refined. Concluding remarks are provided in Section 6, which includes implications for research and practice.

\section{Two-stage method}

This study is based on a two-stage approach. Section 2.1 outlines the systematic literature review method used to deductively develop the conceptual model. This is followed by Section 2.2 in which the single case study method used to refine the framework is outlined.

\subsection{Systematic literature review}

A systematic literature review (SLR) has been conducted (see Tranfield et al. 2003; Denyer and Tranfield 2009). Although other approaches exist, such as semi-structured (Quintens et al. 2006) and more organic reviews (e.g. Spina et al. 2013), the SLR provides a replicable, scientific and transparent method that minimises bias (Tranfield et al. 2003).

This review is based on a structured search of the abstract field in the ABI/INFORM and EBSCO Business Source Premier databases. These two databases have also been used in reviews of other operations management related phenomena (e.g. Mugurusi and de Boer 2013; Zorzini et al. 2015). The following keywords were used individually: "Backshoring", "Reshoring", "Back-reshoring", "Back-Shoring", "Backsourcing", and "Re-shoring". The terms emerged from the literature and were validated by multiple researchers. The search was limited to published, scholarly peer-reviewed journals in English with no date restriction applied due to the nascent state of the literature.

The results were aggregated into a single list of 99 papers, reduced to 59 after removing duplicates. To maintain the quality of the articles reviewed, only those published in journals rated in the 2015 ABS Academic Journal Guide were included, which reduced the list further to 42 . This method of elimination was also used in Zorzini et al. (2015) based on an earlier version of the guide. The abstracts were then checked manually for relevance. Irrelevant papers, e.g. using a term in a completely different sense, were removed, which reduced the list to 32 papers. Cross-referencing was undertaken to ensure all relevant citations had been captured. This identified an additional 10 papers, including two recent conference papers. Incorporating these papers was deemed appropriate given the contemporary nature of the topic. Hence, the final database contains 42 papers (published between 2007 and 2017), which are marked with an asterisk in the reference list at the end of this paper. The high proportion of papers added after the keyword search reflects the nascent state of the 
literature resulting in a diverse range of terms being used to describe the same phenomenon.

Each paper has been carefully reviewed to identify aspects of the reshoring process, with the detail recorded in a spreadsheet (e.g. author(s), date, journal, drivers, implementation process, method, industry sector, and country focus).

\subsection{Single case study}

The case study method lends itself to early, exploratory research on a new or under-researched phenomenon (McCutcheon and Meredith 1993; Yin 2009; Voss et al. 2016). A single case study approach has been adopted (e.g. Eisenhardt 1989; Yin 2009) to allow the researchers to go into greater depth exploring retrospective and future decisions in a firm that satisfies the following criteria:

- Previously embarked on captive offshoring; and,

- Has recently either partially or fully reshored in-house production activities.

A company, hereafter referred to as "Cushion Co.", was selected that satisfied these criteria. Cushion Co. is an SME that has recently partially reshored its production from a factory in China to the UK where it was founded in 1991. The company designs and manufactures cushions for global retailers, with a growing annual turnover, currently at approximately $£ 8$ million. Although reshoring in the context of sourcing decisions is reasonably widespread, captive reshoring is still relatively uncommon. The company is an early mover in terms of reshoring. As a result, it is one of the few examples of a company that has successfully reshored and has therefore been used as an exemplary case in the media.

A series of semi-structured interviews were conducted with the Owner and Marketing Manager over a 12-month period at the company's UK facility. A case study protocol was followed to improve reliability and ensure replicability (Yin 2009; Voss et al. 2016). For the initial interviews, a set of open-ended questions were developed around the company's global manufacturing strategy and history of location decisions. The questions were sent to the interviewees in advance. Interviews were recorded and transcribed, with transcripts sent back to interviewees for validation. A timeline was then developed to understand the case (see Table 1) before the transcripts were analysed with the support of Nvivo (C) software. This included coding the data according to the different elements of the initial deductive framework; and identifying key factors that did not fit into the initial framework in order to refine it.

Analysis of the initial data allowed a more in-depth set of questions to be developed to further probe and understand the reshoring process. The interviews were supplemented with secondary data from company documentation and their website, plus six television programmes and five news articles on reshoring that featured the company to provide triangulation. The case findings (see Tables 2, 3, and 4) provide a summary of the primary and secondary evidence.

\section{Deductive development of the framework using prior literature}

This section reviews the extant literature that has led to the deductive development of the conceptual framework. Figure 1 provides an outline for the framework, which will be populated through this review and presented in Section 3.4. The framework is comprised of the following three key elements: reshoring drivers; implementation considerations; and, contingency factors. Each factor was placed within its dominant
Fig. 1 Outline Conceptual Framework

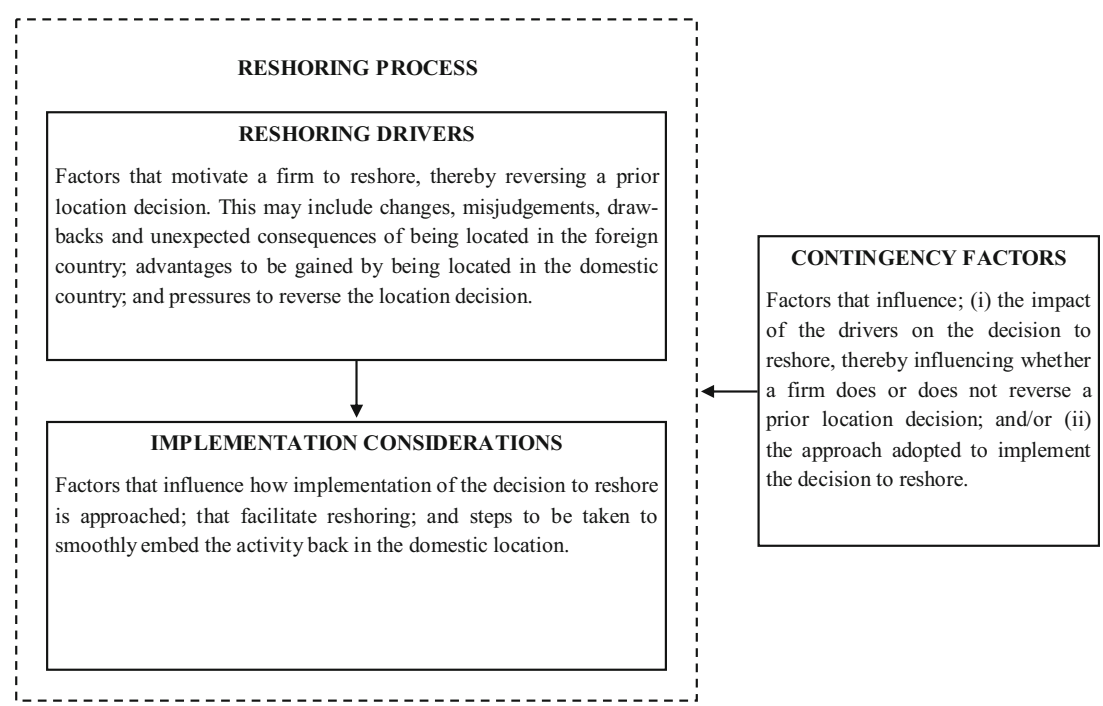


category by two researchers independently before any differences were discussed and a final categorisation agreed amongst three researchers. The review considers each of the elements of the framework in turn: Section 3.1, the reshoring drivers; Section 3.2, implementation considerations; and Section 3.3, contingency factors.

\subsection{Reshoring drivers}

The drivers behind the reshoring decision have been further split into the following four categories:

- Risk, uncertainty and ease of doing business (Section 3.1.1): reshoring to reduce exposure to risk, uncertainty, and/ or allow (equally or more) efficient operations to be run in the domestic location.

- Cost-related (Section 3.1.2): reshoring to reduce certain costs, including when the costs of operating offshore were unexpected, hidden or greater than expected.

- Infrastructure-related (Section 3.1.3): reshoring to overcome or avoid infrastructure issues (e.g. site, labour, materials, and machinery) or to access better infrastructure in the domestic location.

- Competitive priorities (Section 3.1.4): reshoring to support the operations strategy and competitive priorities of the firm, particularly those that are not directly cost related.

\subsubsection{Risk, uncertainty and ease of doing business}

Drivers have been included in this category if they motivate a firm to move onshore to reduce risk, uncertainty and allow (equally or more) efficient operations to be run in the domestic location. There can be a drive to reshore to reduce the supply chain disruption risk that is inherent to dispersed and extended global networks (Bailey and De Propris 2014; Simchi-Levi et al. 2012; Tate 2014; Huq et al. 2016). The cultural distance between offshore and domestic locations (e.g. communication and language barriers) can also make it difficult to operate offshore and incentivise reshoring (Gray et al. 2013; Tate 2014). Meanwhile, reshoring has been linked to offshore legislation that complicates business transactions and operations (e.g. Martínez-Mora and Merino 2014). Unpredictable global economic conditions can influence reshoring; for example, Kinkel (2012) suggested companies are more likely to re-concentrate production domestically when the global economy is unstable. A related factor is currency exchange rates and variability. The strengthening of the Chinese currency, for example, has increased the cost of imports (Martínez-Mora and Merino 2014; Pearce 2014; Gylling et al. 2015), while the risk of currency fluctuations increases the appeal of domestic locations (Leibl et al. 2010; Tate et al. 2014).
Reshoring can also be motivated by a desire to reduce the risk of environmental and social issues (Gray et al. 2013; Tate et al. 2014; Presley et al. 2016), which can impact firm reputation. Few authors have highlighted these concerns, yet they may become increasingly important. For example, Gray et al. (2013) highlighted the green motivations behind reshoring, e.g. carbon footprint reduction and Tate et al. (2014) highlighted the reputational risk of environmental and/or human rights violations. Meanwhile, Presley et al. (2016) found in their interviews that greater importance is placed on environmental than social issues during location decision making.

\subsubsection{Cost-related drivers}

Although the reshoring decision is dependent on multiple variables, costs that were unexpected, hidden or greater than expected can make a domestic location more attractive. Labour costs are a key issue with a closing wage gap between domestic and offshore locations (Pearce 2014; Simchi-Levi et al. 2012; Wu and Zhang 2014). Additionally, labour productivity improvements may also be available in the domestic location and offset any remaining foreign wage differentials (Pearce 2014; Tate 2014; Hartman et al. 2017). Meanwhile, a desire to reduce duty costs can influence reshoring; for example, Fratocchi et al. (2016) referred to the impact of 'custom duties for re-import'. In addition, domestic production lowers transportation costs (Bailey and De Propris 2014; Tate et al. 2014) while attractive energy prices (in the US) have been highlighted as lowering both transportation costs and (non-labour) production costs (Pearce 2014). Gylling et al. (2015), for example, found that production cost reductions enabled a Finnish bicycle firm to compete with its offshore contract manufacturer, allowing activities to be brought both back onshore and in-house.

Kinkel and Maloca (2009) and Kinkel (2012) recognised the high coordination and monitoring costs of offshore locations that increase overheads (e.g. travel costs), particularly for captive offshore firms (Kinkel 2014). Offshoring can also result in higher working capital/ pipeline costs, including high inventories in transit or distribution centres (Tate et al. 2014). Martínez-Mora and Merino (2014) highlighted how switching to domestic suppliers can create smaller, more frequent orders that reduce inventory costs. Finally, Kinkel and Zanker (2013) found that reshoring improves domestic capacity utilisation thus lowering overheads. This may be particularly relevant to firms that have retained a domestic presence when offshoring.

\subsubsection{Infrastructure-related drivers}

Firms are motivated to reshore if there are issues with the offshore infrastructure (such as the site, labour, materials and machinery) or access to an improved infrastructure can be 
obtained in the domestic location. Kinkel and Maloca (2009) and Kinkel and Zanker (2013) identified on-site infrastructure issues offshore as a potential reshoring driver. Kinkel and Maloca (2009) also highlighted that firms can find it difficult to establish a reliable raw material supply network offshore. Meanwhile, concerns around skilled human resource availability can influence reshoring. This includes a lack of availability offshore (Bailey and De Propris 2014; Simchi-Levi et al. 2012; Stentoft et al. 2016b) and concerns about the deskilling of domestic labour due to extensive offshoring (Bailey and De Propris 2014; Shih 2014). Indeed, it is noted that high domestic unemployment and union pressure is also driving reshoring (Tate 2014; Fratocchi et al. 2016). Finally, some researchers (e.g. Arlbjørn and Mikkelsen 2014; Tate et al. 2014) have argued that an increased reliance on automated machinery could negate higher onshore labour costs, while Dachs and Kinkel (2013) highlighted the quality and flexibility benefits of automation.

\subsubsection{Competitive priorities}

Firms can be motivated to reshore in pursuit of (non-costrelated) competitive priorities. Survey evidence has highlighted that reshoring can improve flexibility and dependability (Kinkel and Maloca 2009; Kinkel 2012; Kinkel and Zanker 2013), reducing the risk of late delivery penalties and improving customer satisfaction (Ancarani et al. 2015; Fratocchi et al. 2016). Additionally, reshoring can improve responsiveness due to closer customer proximity (Fratocchi et al. 2016; Pearce 2014; Tate et al. 2014; Srai and Ané 2016; Moradlou et al. 2017). Reshoring can also be motivated by speed to market improvements for new products (Pearce 2014) and by innovation potential, e.g. from co-locating $\mathrm{R} \& \mathrm{D}$ and manufacturing and investing in technology (McIvor 2013; Pearce 2014; Shih 2014; Stentoft et al. 2016c). Domestic production also facilitates know-how retention (Kinkel 2014) and improves intellectual property protection (Tate 2014; Tate et al. 2014), which might be particularly relevant to firms that have outsourced production.

Reshoring may also improve quality (Kinkel et al. 2007; Kinkel and Maloca 2009; Kinkel 2012; Kinkel and Zanker 2013; Zhai et al. 2016). For example, Canham and Hamilton's (2013) survey data from New Zealand showed that lower wages offshore were offset by quality problems, while Uluskan et al. (2016) found domestic US suppliers achieved higher quality than some international competitors. Finally, companies can also capitalise on 'made in effect' advantages by producing domestically, which adds value for local customers such as perceived quality benefits (Martínez-Mora and Merino 2014; Tate et al. 2014; Fratocchi et al. 2016; Srai and Ané 2016). Grappi et al. (2015), for example, tested consumer responses to reshoring and found that companies can improve their image by reshoring.

\subsection{Implementation considerations}

Fratocchi et al. (2014) recommended that research consider how firms reshore in terms of the entry and exit modes both onshore and offshore. They acknowledged that the entry mode to the foreign location can impact the exit strategy and argued that firms that have not built a factory offshore can withdraw more easily. Equally, the entry mode back into the home location also needs to be considered. Similar to offshoring, reshoring is typically defined in terms of location and ownership, i.e. the ownership both onshore and offshore. In their literature review, Jahns et al. (2006) provided a matrix to illustrate this in the context of offshoring, and this has been adapted for reshoring by Foerstl et al. (2016) and Tate and Bals (2017) to depict the reshoring movement from offshore to onshore (including nearshore) and the corresponding ownership options. Firms may, for example, bring activities inhouse when reshoring from an outsourced supplier. Similarly, Gray et al. (2013) provided a typology that presents eight different reshoring paths that consider ownership before and after an offshoring decision, thereby summarising how ownership can change as firms relocate. This does not however detail how firms have actually achieved this in practice. Meanwhile, in their conceptual model for location decision making, Joubioux and Vanpoucke (2016) considered the initial decision making process, including the entry modes for the initial offshore decision, but their model did not detail the ownership options onshore.

In Gylling et al.'s (2015) action research with a Finnish bicycle firm, the authors outlined how the company maintained some in-house domestic production for one of its product lines whilst offshoring the majority of production to an overseas supplier. This enabled the subsequent decision to reshore and demonstrated how maintaining production in a domestic location whilst offshoring can facilitate reshoring. The authors' case also shows the degree of reshoring, in this instance a partial reshoring approach - as only a certain product line was brought back. Martínez-Mora and Merino (2014) also provided examples of companies that have reshored but continued to produce offshore.

Bailey and De Propris (2014) discussed barriers that must be overcome to operationalise the reshoring decision, including gaining access to labour and finance. For example, the authors referred to a fragmented manufacturing supply chain and skills gap in the UK as a result of extensive prior offshoring. Similar findings were noted in the US context by Shih (2014) who emphasised the importance of in-house training to improve skills and employee retention. The author also recommended building strong relationships with suppliers and improving information sharing with suppliers. 


\subsection{Contingency factors}

A further eleven factors are categorised here as contingency factors - they are aspects of the context that influence whether a set of drivers lead a firm to reshore and/or how that decision is implemented. Although the literature provides examples of issues that can be considered contingency factors, there is a need to explicitly adopt a contingency perspective to further understand indirect influences throughout the reshoring process. Despite contingency factors having been identified in the offshoring literature (e.g. Mukherjee et al. 2013; Zorzini et al. 2014), to the best of our knowledge, such a contingency-based approach to understanding the reshoring phenomenon has not been adopted in the prior literature although it has recently been encouraged by Bals et al. (2016).

The first contingency factor is the size of the firm. Kinkel (2012) found that the majority of firms that reshore are large firms with more than 500 employees - as large firms are more active in offshoring. Yet the author also found evidence that large companies are reducing their reshoring activities and the number of SMEs reshoring is increasing. Ancarani et al. (2015) found that those SMEs that do reshore do so earlier than larger firms; and this might be explained by an unwillingness or inability to fund any difficulties faced offshore (Kinkel 2012). A second contingency factor is the ownership mode (e.g. captive or outsourced), which could influence the weight given to some of the reshoring drivers (e.g. know-how retention) as well as influencing when and how a firm reshores (given its impact on how embedded the firm would be in the foreign location). This appears to be supported by Kinkel (2014) who differentiated between captive and outsourced reshoring when analysing the reasons for repatriation. In addition, government policy, such as domestic government incentives, i.e. reduced taxes and subsidies, can lower costs and encourage reshoring (Ellram et al. 2013; Bailey and De Propris 2014; Pearce 2014; Tate et al. 2014). Bailey and De Propris (2014) also considered how the government could provide firms with financial aid for implementing the reshoring decision and with help in closing the skills gap. Capital intensiveness can also influence reshoring. For example, Dachs and Kinkel (2013) provided a brief breakdown of the industries active in reshoring using European survey data. They concluded that low technology industries are less likely to reshore due to the high labour content, which implies being located in lower wage countries. Similarly, technology-based industries such as electronics and automotives have been identified as likely to reshore (Ancarani et al. 2015). Further, Stentoft et al. (2016a) argued that industry related factors could influence reshoring. Bandwagon effects (and competitive pressure) are known to have influenced offshoring and could similarly affect the decision to reshore (Kinkel 2012; Gray et al. 2013; Martínez-Mora and Merino 2014). There may not for example be a strong internal drive to reshore but the outcome of the decision process could be impacted by the actions of competitors. In addition, MartínezMora and Merino (2014) found that the attractiveness of reshoring within the clothing and textiles sector depends on the market segment (e.g. sportswear and dress shoes) and price point (e.g. low-range, mid-range products, etc.). Meanwhile, Tate (2014) highlighted that the bulkiness of the product (size, weight, etc.) could influence whether products are ultimately reshored. In addition, Bailey and De Propris (2014) referred to customised products, involving the user as a co-producer of the design, being facilitated by co-locating manufacturing and design.

The management's perception of cost could also influence location decisions. Both Gray et al. (2013) and Kinkel (2014) suggested that reshoring could be as a result of prior misjudgements in the offshoring decision making process whereby the costs of operating offshore were underestimated. Equally, a firm might reshore because the investment required to improve the offshore conditions were over-estimated. Finally, emotional factors can lead to a firm (or decision maker) having an attachment to the domestic location (Fratocchi et al. 2016) thereby increasing the influence given to drivers on the decision to reshore, and this is thought to be particularly prevalent amongst entrepreneurs. Similarly, Canham and Hamilton (2013) referred to patriotism or patriotic effects in their research on SMEs.

\subsection{Conceptual framework}

The extant literature reviewed above leads to the deductive development of a conceptual framework of the reshoring process, as presented in Fig. 2. The framework focuses on the reshoring decision process and thus complements earlier conceptual frameworks that have focused on the prior offshoring process. Yet whilst offshoring research has considered the relationship between drivers, governance modes and firm size (see for example Roza et al. 2011; Caniato et al. 2015), this stream of literature is driver focused and assumes that the right location for the operation is offshore. Our framework considers reversing this decision, but by adopting a contingency perspective acknowledges that the right location - on or offshore - is dependent on various factors. Moreover, existing models for both offshoring (e.g. Patrucco et al. 2016) and reshoring (Joubioux and Vanpoucke 2016) have tended to focus on the decision making process rather than supporting a firm through the transition by providing a structure for the entire relocation process.

Each element in the framework shown in Fig. 2 has been briefly unpacked above although space restrictions preclude a detailed discussion. Our aim has been to cite literature to justify the inclusion of each factor in our framework thereby providing an audit trail behind its development. In summary, the framework is comprised of: (i) 29 drivers behind the reshoring decision; (ii) six implementation considerations relating to the operationalisation of this decision; and, (iii) eleven contingency factors that affect the decision to reshore and/ or how this is implemented. 


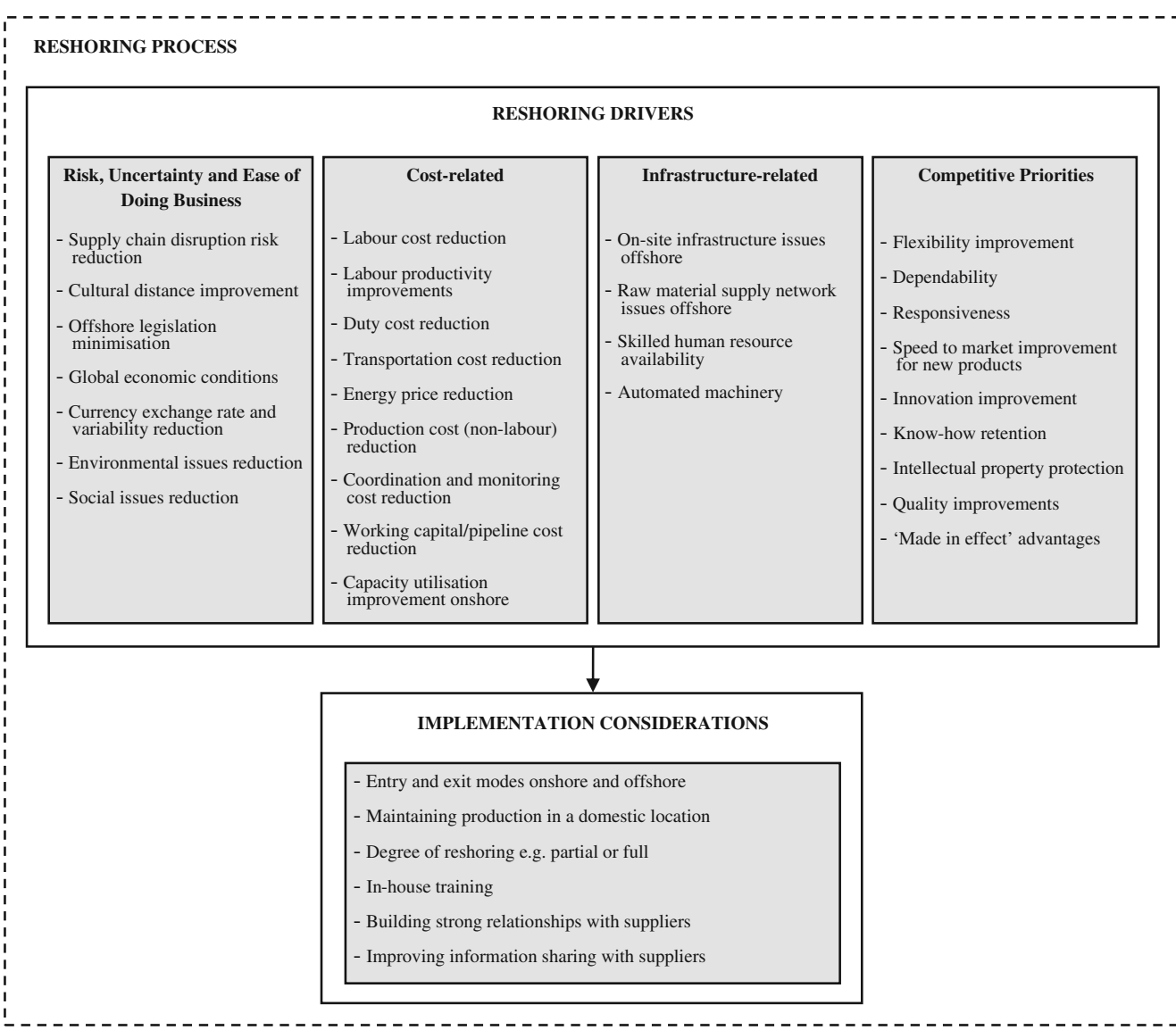

CONTINGENCY FACTORS

Size of the firm

- Ownership modes

- Government policy

- Capital intensiveness

- Bandwagon effects

Market segments (e.g. product area)

Price points (e.g. low-range, mid-range etc.)

Bulkiness of the product (size, weight, etc.)

- Customised products

- Management's perception of cost

Emotional factors

Fig. 2 Conceptual Framework of the Reshoring Process based on the Prior Literature

\section{Case study evidence}

\subsection{Overview of Cushion Co.}

Cushion Co. designs and manufactures cushions and related products for global retailers. As shown in Table 1, the company was established in 1991 in the UK. In 2003, it opened a second UK factory with government support and began gradually offshoring to China. It then closed its original UK factory and the Chinese operation grew. It opened a purpose-built Chinese factory in 2007, which was extended in 2010 to a 250,000 square foot factory. In 2012, it began to reshore some activities to the UK and sold its Chinese factory, maintaining a smaller rented facility. Before offshoring, Cushion Co. had a UK workforce of up to 100 staff, which fell to around 30 at the height of offshoring. The UK workforce is now growing again and is currently up to around 60 staff. Table 1 also shows how the company's ownership modes have evolved over time, as further discussed below.

The case narrative below begins with an overview of the prior offshoring decision. Although this is not the focus of this paper, an understanding of this decision is important to gaining a full understanding of the subsequent reshoring decision. The reshoring process is then described and will be later analysed in Section 5.

\subsection{The prior offshoring decision at Cushion Co.}

China's entry into the World Trade Organisation led to foreign investment in China and an influx of Chinese products into the global market. The favourable exchange rate meant Chinamade products were cheap, making it difficult for UK production to compete. Cushion Co. found that Chinese competitors had selling prices lower than their cost prices. They were under constant customer pressure to reduce prices. The owner explained that they started to produce in China because "at the time, it was literally China or bust [go out of business]".

Having decided to offshore to China, the owner described the process as "step-by-step". Chinese fabrics were first imported to reduce domestic production costs in 2003. The company then decided in 2004 to offshore outsource to China to further reduce costs. After a trial, which established this as a viable solution, the company then established a joint venture with the Chinese supplier. Cushion Co. had a $70 \%$ stake, which meant customers recognised it as a legitimate Cushion Co. operation rather than an intermediary. This was critical as retailers were keen to buy directly from factories in China. In 2007, a purpose-built factory was opened, with the joint venture partner key to establishing a good local workforce.

Back in the UK, the company closed one of its two factories. It arranged a daily bus service to transport skilled 
Table 1 Location and Ownership Timeline of the Case Study Company (Cushion Co.)

\begin{tabular}{|c|c|c|c|c|c|c|c|c|c|}
\hline & 1991 & 2003 & 2004 & 2005 & 2007 & 2010 & 2011 & 2012 & 2015 \\
\hline \multirow{2}{*}{ 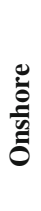 } & $\begin{array}{l}\text { Opened } 1^{\text {st }} \mathrm{UK} \\
\text { factory }\end{array}$ & $\begin{array}{l}\text { Opened } 2^{\text {nd }} \text { UK } \\
\text { factory }\end{array}$ & & \multirow{2}{*}{$\begin{array}{l}\text { Closed } 1^{\text {st }} \mathrm{UK} \\
\text { factory; } \\
2^{\text {nd }} \text { UK factory } \\
\text { remains } \\
\\
\text { (Wholly Owned, } \\
\text { Captive Onshore) }\end{array}$} & & & & \multirow{2}{*}{$\begin{array}{l}\text { Reshoring process } \\
\text { begins to UK } \\
\text { factory } \\
\text { (Wholly Owned, } \\
\text { Captive Onshore) }\end{array}$} & \multirow{2}{*}{$\begin{array}{c}10-15 \% \text { of } \\
\text { production reshored } \\
\text { from China to the } \\
\text { UK } \\
\text { (Wholly Owned, } \\
\text { Captive Onshore) }\end{array}$} \\
\hline & $\begin{array}{l}\text { (Wholly Owned, } \\
\text { Captive Onshore) }\end{array}$ & $\begin{array}{l}\text { (Wholly Owned, } \\
\text { Captive Onshore) }\end{array}$ & & & & & & & \\
\hline \multirow{2}{*}{$\frac{0}{\frac{0}{0}}$} & \multirow{2}{*}{$N / A$} & \multirow{2}{*}{$\begin{array}{l}\text { Offshore process } \\
\text { begins - started to } \\
\text { import Chinese } \\
\text { fabrics for UK } \\
\text { production }\end{array}$} & $\begin{array}{l}\text { Sourcing from a } \\
\text { small manufacturer } \\
\text { in China }\end{array}$ & & \multirow{2}{*}{$\begin{array}{c}\text { Purpose built } \\
\text { factory opened in } \\
\text { China - joint } \\
\text { venture with } \\
\text { previous Chinese } \\
\text { supplier } \\
\text { (Joint Venture, } \\
\text { Captive Offshore) }\end{array}$} & \multirow{2}{*}{$\begin{array}{l}\text { China factory } \\
\text { extended to create } \\
\text { more capacity } \\
\text { (Joint Venture, } \\
\text { Captive Offshore) }\end{array}$} & \multirow{2}{*}{$\begin{array}{l}\text { Ended joint venture } \\
\text { and established a } \\
\text { Wholly Foreign } \\
\text { Owned Enterprise } \\
\text { (WFOE) } \\
\text { (Wholly Owned, } \\
\text { Captive Offshore) }\end{array}$} & \multirow{2}{*}{$\begin{array}{l}\text { China premises } \\
\text { sold; moved to } \\
\text { smaller rented } \\
\text { factory }\end{array}$} & \\
\hline & & & $\begin{array}{l}\text { (Offshore, } \\
\text { Outsource) }\end{array}$ & & & & & & \\
\hline
\end{tabular}

machinists, which were in short supply, from the closed to the one remaining open factory, which became the headquarters. The Marketing Manager explained: "To lose those people [i.e. skilled machinists, would be very problematic], you wouldn't be able to replace those skills". The UK operation focused on filling cushions as it was expensive to ship filled cushions from China. The company also moved up market for any production that remained in the UK.

The Chinese factory was extended in 2010 to cope with demand. The Chinese business had started small but quickly grew. This organic approach meant it did not require major start-up investment. UK personnel travelled to China regularly, e.g. to implement quality systems and make productivity improvements. The owner explained that this transformed the factory from "local [domestic] to export [world] class", ensuring it passed retailer audits. Although formal systems and practices were transferred, Cushion Co. found it difficult to recreate innovation processes. The China factory was not successful at producing its own designs or intellectual property; and the design function, $\mathrm{R} \& \mathrm{D}$ and sampling operations remained in the UK. The Chinese operation was however involved in sourcing materials as it was located close to a cluster of readily available suppliers. The company also realised its location could provide market access not only to China but to Australia and Western USA. This led to the introduction of a Chinese sales function.

\subsection{The reshoring decision at Cushion Co.}

When Cushion Co. had offshored, favourable exchange rates and low Chinese labour costs helped it compete. The Chinese currency however appreciated over time while UK costs increased at a slower rate due to the West's economic downturn. Chinese wages were also rising as demand for labour outstripped supply. Further, the lower wage argument was never particularly strong as the simplicity of cushions means labour content is a small proportion of the total production cost. The attractiveness of China was worsened by high duty rates. The owner explained that: "the duty rate on finished goods is higher than on fabric, and duty is also applied to the freight, to the profit made by the Chinese factory, the packaging, etc." In addition, cushions are large and expensive to ship when pre-filled. Overall, this made it arguably more cost-effective to use Chinese fabric but manufacture and/or fill the cases in the UK.

The owner referred to the above as key "cost-push reasons" to reshore. But UK manufacturing was also considered "less aggravation", avoiding cultural differences, language barriers and time zone problems. Cushion Co. had also started to experience problems with their Chinese partner, which had opportunistically tried to establish a rival firm. They ended the joint venture in 2011 after changes to Chinese law enabled them to establish a Wholly Foreign Owned Enterprise (WFOE). This gave Cushion Co. more control - it made withdrawal from China more straightforward whilst ensuring that their knowhow was retained and intellectual property protected.

Reshoring also had advantages for their main UK customers. The owner explained that: "you are much more efficient if you are working alongside your customer [retailers] rather than waiting and doing business via email the next day". There was a desire to be more responsive to customers - to shorten lead times and get new products to market quicker. The "Made in the UK" label was also attractive to customers. In addition, there was a desire to increase the workforce and capacity utilisation in the UK where better quality and productivity were available, although the observable productivity gap was shrinking due to improvements made at the Chinese factory. 
Just a few of the above factors may not have been a major concern, but when added together they built a persuasive argument to reshore, especially given the owner's nostalgic attachment to the UK. He explained that: "we have always wanted to and preferred to manufacture at home [i.e. in the UK]". Even when it offshored, Cushion Co. had maintained a UK presence while its competitors had either fully offshored or retained only a UK sales function. The owner explained he had been criticised for being "sentimental" but claimed this had always been "a very important strategic decision". He explained: "the ability to make the product either in the East or West [from a UK perspective] gives us flexibility ... to react to whatever the global economy and the marketplace throws at us". As part of this strategy, the company produced a range of lower volume, higher priced products mainly in the UK.

Cushion Co. increased its UK operation and downsized its China operation, with its experience of offshoring helpful in how this was approached. The owner stressed that: "[you cannot] just drop [i.e. close] a factory on one side of the world and open one on another". He explained: "we used the same model that we first used to offshore to reshore - we did it step by step again". Their first step towards offshoring had involved using Chinese fabrics in UK production. So, in reverse, when production was reshored, they again used Chinese fabrics. The UK workforce was gradually increased, although recruiting skilled machinists was challenging due to the high level of offshoring within the sector. The company has an ageing workforce and there is a lack of new entrants. The company therefore plans to establish in-house training and launch an apprenticeship scheme with government support.

Reshoring was relatively straightforward because Cushion Co. had never fully withdrawn from the UK. It had retained a Western supply chain and workforce; hence, it did not need to re-establish itself. The management team, core skills and machinery were already in place. The owner explained: "we're really just increasing the capacity that we maintained through the offshoring period". He added: "had we [fully offshored] it would have been very difficult to set up again, [reshoring] was actually easier to do because we had a starting point [i.e. a retained domestic base]". The company has UK packaging suppliers; and although there are few remaining UK raw material suppliers, it had maintained relationships with European-based suppliers. Throughout the reshoring process, Cushion Co. ensured that suppliers, customers and staff (UK and China based) were kept informed.

Since reshoring, the company has sold its Chinese premises and moved to a smaller, rented facility that remains important, e.g. for serving the Eastern market. But recent changes, including the introduction of a new UK national living wage and devaluation of the Chinese currency, threaten to make the trend towards reshoring temporary. Meanwhile, it remains to be seen how the UK's withdrawal from the EU will affect the company's location decisions.

\section{Discussion and framework refinement}

This section analyses the case evidence to refine the conceptual framework. It is therefore organised around the key headings from the initial framework (Fig. 2).

\subsection{Reshoring drivers}

Table 2 compares the reshoring drivers from the literature with those relevant to the case. Cushion Co. provides evidence for 20 of the original 29 drivers, with new insight into their influence provided. Factors from each of the four categories influenced Cushion Co.'s decision to reshore. The category with the most factors evident is Competitive Priorities (9), followed by Cost-related (6), Risk, Uncertainty and Ease of Doing Business (3), and Infrastructure-related (2). The most important individual factors were labour and duty costs (Costrelated category) and currency exchange rate and variability reduction (Risk, Uncertainty and Ease of Doing Business category). Each category is briefly discussed below.

\subsubsection{Risk, uncertainty and ease of doing business}

The most significant driver in this category was currency exchange rate and variability reduction, confirming earlier findings relating to Chinese currency appreciation (e.g. Martínez-Mora and Merino 2014; Pearce 2014; Gylling et al. 2015). The decision to reshore was also driven by changing global economic conditions, in particular Chinese economic growth and the Western downturn, which supports Martínez-Mora and Merino (2014). Reshoring was further motivated by the need to overcome issues relating to cultural distance. Gray et al. (2013) and Tate (2014) raised concerns about cultural distance when operating offshore, and Cushion Co. provides case evidence to support this factor. Reshoring was not however strongly motivated by supply chain disruption risk reduction, offshore legislation minimisation, environmental issues reduction or social issues reduction. These factors may however be relevant in other cases.

\subsubsection{Cost-related drivers}

Cost savings are a key theme in both the literature and Cushion Co., including labour costs (e.g. Pearce 2014; Simchi-Levi et al. 2012; Wu and Zhang 2014). The case supports Pearce (2014) and Tate (2014) by providing case evidence that labour productivity improvements can be achieved through domestic production further lowering costs, even if the productivity gap is reducing. Duty cost reduction is also significant in Cushion Co. and this has only previously been highlighted by Fratocchi et al. (2016) based on secondary data. In addition, concerns about transport costs between China and the West support those in the literature (Bailey and 
Table 2 Summary of Reshoring Drivers, Including Source of Case Evidence (if any)

\begin{tabular}{|c|c|c|c|c|}
\hline Category & Driver & $\begin{array}{l}\text { Primary } \\
\text { Data }\end{array}$ & $\begin{array}{l}\text { Secondary } \\
\text { Data }\end{array}$ & Explanation from the Case Study \\
\hline \multirow{7}{*}{$\begin{array}{l}\text { Risk, Uncertainty and Ease } \\
\text { of Doing Business }\end{array}$} & Supply chain disruption risk reduction & & & Not identified as a factor in this case \\
\hline & Cultural distance improvement & $\checkmark$ & $\checkmark$ & $\begin{array}{l}\text { Bringing some activities back onshore to reduce the } \\
\text { impact of cultural differences (between the UK } \\
\text { and China) }\end{array}$ \\
\hline & Offshore legislation minimisation & & & Not identified as a factor in this case \\
\hline & Global economic conditions & $\checkmark$ & $\checkmark$ & $\begin{array}{l}\text { Growing Chinese economy vs. downturn in the West } \\
\text { increased costs offshore }\end{array}$ \\
\hline & Currency exchange rate and variability & $\checkmark$ & $\checkmark$ & $\begin{array}{l}\text { Currency changes in China reducing incentives to } \\
\text { produce offshore }\end{array}$ \\
\hline & Environmental issues reduction & & & Not identified as a factor in this case \\
\hline & Social issues reduction & & & Not identified as a factor in this case \\
\hline \multirow[t]{9}{*}{ Cost-related } & Labour cost reduction & $\checkmark$ & $\checkmark$ & $\begin{array}{l}\text { Rising Chinese labour costs disincentivise offshore } \\
\text { activities }\end{array}$ \\
\hline & Labour productivity improvements & $\checkmark$ & $\checkmark$ & Higher productivity in the UK compared to China \\
\hline & Duty cost reduction & $\checkmark$ & $\checkmark$ & $\begin{array}{l}\text { To reduce duty costs on finished goods, freight, } \\
\text { packaging, profit on Chinese factory, etc. }\end{array}$ \\
\hline & Transportation cost reduction & $\checkmark$ & $\checkmark$ & $\begin{array}{l}\text { Expensive to ship products from China to Western } \\
\text { customers }\end{array}$ \\
\hline & Energy price reduction & & & Not identified as a factor in this case \\
\hline & Production cost (non-labour) reduction & & & $\begin{array}{l}\text { Not identified as a factor in this case (cost reductions } \\
\text { already introduced in China) }\end{array}$ \\
\hline & $\begin{array}{l}\text { Coordination and monitoring costs } \\
\text { reduction }\end{array}$ & $\checkmark$ & $\checkmark$ & $\begin{array}{l}\text { To create internal efficiencies and enable working } \\
\text { alongside customers in the UK }\end{array}$ \\
\hline & $\begin{array}{l}\text { Working capital/pipeline costs } \\
\text { reduction }\end{array}$ & & & Not identified as a factor in this case \\
\hline & $\begin{array}{l}\text { Capacity utilisation improvement } \\
\text { onshore }\end{array}$ & $\checkmark$ & & $\begin{array}{l}\text { Using UK facilities to rebalance capacity utilisation } \\
\text { between the UK and China }\end{array}$ \\
\hline \multirow[t]{4}{*}{ Infrastructure-related } & On-site infrastructure issues & & & $\begin{array}{l}\text { Not identified as a factor in this case } \\
\text { (strong infrastructure in China) }\end{array}$ \\
\hline & $\begin{array}{l}\text { Raw material supply network issues } \\
\text { offshore }\end{array}$ & $\checkmark$ & $\checkmark$ & $\begin{array}{l}\text { Establishing a global supply network to support UK } \\
\text { production }\end{array}$ \\
\hline & Skilled human resource availability & $\checkmark$ & $\checkmark$ & To allow a skilled workforce to be retained in the UK \\
\hline & Automated machinery & & & $\begin{array}{l}\text { Not identified as a factor in this case (not reliant on } \\
\text { automation) }\end{array}$ \\
\hline \multirow[t]{9}{*}{ Competitive Priorities } & Flexibility improvement & $\checkmark$ & $\checkmark$ & $\begin{array}{l}\text { Dual locations (in the UK and China) allow for } \\
\text { reaction to market needs in both the East and West; } \\
\text { considered strategically important }\end{array}$ \\
\hline & Dependability & $\checkmark$ & $\checkmark$ & $\begin{array}{l}\text { Reshoring to be close to the UK market improving } \\
\text { service and the ability to deliver on time }\end{array}$ \\
\hline & Responsiveness & $\checkmark$ & $\checkmark$ & $\begin{array}{l}\text { Reshoring to be close to the UK market allowing the } \\
\text { firm to compete on speed }\end{array}$ \\
\hline & $\begin{array}{l}\text { Speed to market improvement for } \\
\text { new products }\end{array}$ & $\checkmark$ & $\checkmark$ & $\begin{array}{l}\text { To improve speed to market for the introduction of } \\
\text { new products }\end{array}$ \\
\hline & Innovation improvement & $\checkmark$ & & $\begin{array}{l}\text { To enable co-location of design and production, } \\
\text { enabling innovation }\end{array}$ \\
\hline & Know-how retention & $\checkmark$ & $\checkmark$ & To retain skills and know-how in the UK \\
\hline & Intellectual property protection & $\checkmark$ & & $\begin{array}{l}\text { Perceived to be better protected in the UK from } \\
\text { intellectual property infringements }\end{array}$ \\
\hline & Quality improvements & $\checkmark$ & $\checkmark$ & $\begin{array}{l}\text { To access the higher quality considered to be available } \\
\text { in the UK, allowing the firm to compete on quality }\end{array}$ \\
\hline & 'Made in effect' advantages & $\checkmark$ & $\checkmark$ & $\begin{array}{l}\text { Attractiveness of the 'Made in the UK' hallmark } \\
\text { particularly to the Western market }\end{array}$ \\
\hline
\end{tabular}


De Propris 2014; Tate et al. 2014) while the case also highlights how transportation incurs duty charges. In terms of coordination and monitoring costs, the literature has focused on the overheads of managing offshore production (Kinkel and Maloca 2009; Kinkel 2012; Gray et al. 2013). Similarly, Cushion Co.'s UK management team had to travel to China regularly to train and implement systems. Further costs were incurred when partner relations became strained. Cushion Co. also provides case evidence that supports survey (Kinkel and Zanker 2013) and secondary data (Fratocchi et al. 2016) on capacity utilisation as reshoring has allowed it to make better use of its UK facilities, thus lowering overheads.

Production costs were not a key driver, perhaps due to the improvements made in China that reduced costs. Energy price reduction was also not acknowledged - this was previously highlighted in the US and not the UK context (Pearce 2014). Finally, reshoring was not motivated by working capital/ pipeline cost reduction, but this may be relevant in other cases.

\subsubsection{Infrastructure-related drivers}

The case evidence demonstrated that the decision to reshore was not significantly driven by infrastructure concerns. For example, skilled human resource availability and raw material supply network issues offshore were not direct drivers, although related issues have facilitated reshoring. First, Cushion Co. has had a skilled workforce in China, enabled by its joint venture, but a shortage is now developing, as noted by Pearce (2014) and Tate et al. (2014). Meanwhile, as a UK presence was maintained, Cushion Co. has a skilled domestic workforce that enables reshoring and partly negates the concerns about domestic labour shortages in Bailey and De Propris (2014) and Shih (2014). Second, Cushion Co. has not had difficulties in establishing raw material networks offshore (Kinkel and Maloca 2009) due to a cluster of Chinese suppliers. But equally, by maintaining a Western supply chain, it has also been able to ramp up UK production. On-site infrastructure issues offshore and automated machinery were not evident in the case. Its Chinese location has a strong physical infrastructure and the company is not heavily reliant on machinery.

\subsubsection{Competitive priorities}

All nine competitive priorities were evident to some degree in Cushion Co. The most prominent were flexibility improvements from being able to react to changing market needs (in the East and West); and dependability due to shorter, more predictable domestic lead times, enabling ontime delivery. This evidence complements survey data in the literature (e.g. Kinkel and Maloca 2009; Kinkel 2012; Kinkel and Zanker 2013). Further, the case provides empirical evidence on reshoring being partly motivated by responsiveness due to (domestic) customer proximity allowing the firm to compete on speed (Pearce 2014; Tate et al. 2014). In addition, the case supports Pearce (2014) as speed to market improvement for new products was also a factor.

Meanwhile, Cushion Co. has achieved some quality improvements from reshoring (Kinkel and Maloca 2009; Canham and Hamilton 2013; Kinkel 2012; Kinkel and Zanker 2013), also supporting Uluskan et al.'s (2016) survey data on the impact of quality systems in international suppliers on reshoring. Design and sampling remained in the UK; therefore reshoring was not strongly driven by innovation improvements, although the company now benefits from co-location (McIvor 2013; Pearce 2014; Shih 2014). Cushion Co. also sought to capitalise on 'made in effects'. The literature suggests this is particularly advantageous in the domestic market (Canham and Hamilton 2013; MartínezMora and Merino 2014; Tate et al. 2014; Fratocchi et al. 2016) but the case suggests there are also export advantages, e.g. to the US. Thus, the consumer perspective is relevant to reshoring, as advocated by Grappi et al. (2015). The remaining factors - know-how retention and intellectual property protection - were more marginal once the joint venture had ended but may be prominent in firms that outsource production.

\subsection{Reshoring implementation considerations}

Table 3 summarises the implementation considerations with evidence from the case. All six original factors are supported by the case, which provides deeper insight into each one. In addition, four new factors are identified; hence, the case provides a strong contribution to enhancing this part of the conceptual framework.

The entry and exit modes of Cushion Co. add to our understanding of the reshoring process. The company's relocation process can be understood in terms of ownership both onshore and offshore, as depicted in Fig. 3. The figure expands upon one of the eight paths from Gray et al.'s (2013) typology. The authors' typology helps us to understand the various ownership and location permutations available as firms move from onshore to offshore and back again whilst also potentially switching from in-house (captive) to outsourcing (or vice versa). The first path from the authors' model involves domestic in-house to offshore in-house to domestic in-house. The case however shows that this can be a somewhat simplistic representation of the reshoring process. First, Cushion Co. only partially offshored, retaining a UK location, which was not considered in the original typology. Second, whilst offshore, incremental ownership changes took place from offshore outsourcing to a joint venture and inhouse production. With the exception of Joubioux and Vanpoucke (2016), the reshoring literature only compares inhouse with outsourced production (e.g. Gray et al. 2013; 
Table 3 Summary of Implementation Considerations, including Source of Case Evidence

\begin{tabular}{|c|c|c|c|c|}
\hline Category & Implementation Consideration & $\begin{array}{l}\text { Primary } \\
\text { Evidence }\end{array}$ & $\begin{array}{l}\text { Secondary } \\
\text { Evidence }\end{array}$ & Explanation from the Case Study \\
\hline \multirow[t]{5}{*}{$\begin{array}{l}\text { Location, Ownership } \\
\text { and Timing }\end{array}$} & $\begin{array}{l}\text { Entry and exit modes onshore } \\
\text { and offshore }\end{array}$ & $\checkmark$ & $\checkmark$ & $\begin{array}{l}\text { Consideration of how the firm will enter the domestic location } \\
\text { and exit from the offshore location. For Cushion Co., exit } \\
\text { from China was more straightforward from owned (captive) } \\
\text { production facilities. The offshore premises were sold and } \\
\text { the company moved to a smaller factory; entry into the UK } \\
\text { enabled by owned production facilities. Various ownership } \\
\text { permutations available as firms move between domestic and } \\
\text { offshore locations. Case evidence of outsourcing, joint } \\
\text { venture agreement, and captive offshoring in China. } \\
\text { In-house production in the UK. }\end{array}$ \\
\hline & $\begin{array}{l}\text { Maintaining production in a } \\
\text { domestic location }\end{array}$ & $\checkmark$ & $\checkmark$ & $\begin{array}{l}\text { Understanding how maintaining production in a domestic } \\
\text { location can facilitate the reshoring process. Cushion Co. } \\
\text { previously maintained a down-sized operation in the UK } \\
\text { whilst offshoring the majority of production to China } \\
\text { resulting in retained UK staff, machinery, management, } \\
\text { and systems. }\end{array}$ \\
\hline & $\begin{array}{l}\text { Degree of reshoring e.g. partial } \\
\text { or full }\end{array}$ & $\checkmark$ & $\checkmark$ & $\begin{array}{l}\text { All production does not need to be transferred to the domestic } \\
\text { location. Since reshoring, production has been partially } \\
\text { retained in China to serve different markets. }\end{array}$ \\
\hline & Tipping point for relocation & $\checkmark$ & $\checkmark$ & $\begin{array}{l}\text { Awareness of when to trigger the reversal process. In Cushion } \\
\text { Co. the case for reshoring began to build and could not be } \\
\text { ignored; for example, the cost between offshore and } \\
\text { onshore production became marginal. }\end{array}$ \\
\hline & $\begin{array}{l}\text { Process of implementation } \\
\quad \text { (incremental vs instantaneous) }\end{array}$ & $\checkmark$ & $\checkmark$ & $\begin{array}{l}\text { Understanding reshoring within the context of prior and } \\
\text { future location decisions is important. Cushion Co. } \\
\text { gradually offshored and subsequently gradually reshored. }\end{array}$ \\
\hline \multirow[t]{5}{*}{$\begin{array}{r}\text { Operations and Supply } \\
\text { Chain Development }\end{array}$} & In-house training & $\checkmark$ & $\checkmark$ & $\begin{array}{l}\text { In-house training to help overcome skills shortage. Cushion } \\
\text { Co are currently in the process of considering this option. }\end{array}$ \\
\hline & $\begin{array}{l}\text { Building strong relationships with } \\
\text { suppliers, internal teams } \\
\text { and customers }\end{array}$ & $\checkmark$ & $\checkmark$ & $\begin{array}{l}\text { Developing strong relationships can aid reshoring. Case } \\
\text { evidence demonstrated that this was important with internal } \\
\text { teams and customers (not identified in the literature) and } \\
\text { suppliers throughout the relocation process. }\end{array}$ \\
\hline & $\begin{array}{l}\text { Improving information sharing } \\
\text { with suppliers, internal teams } \\
\text { and customers }\end{array}$ & $\checkmark$ & $\checkmark$ & $\begin{array}{l}\text { Information sharing can aid reshoring. Case evidence } \\
\text { demonstrated that this was important with internal teams and } \\
\text { customers (not identified in the literature) and suppliers } \\
\text { throughout the relocation process. }\end{array}$ \\
\hline & Market movement & $\checkmark$ & $\checkmark$ & $\begin{array}{l}\text { Market movement may be necessary to facilitate reshoring. } \\
\text { Cushion Co. moved up market onshore and developed } \\
\text { relationships with customers purchasing higher value } \\
\text { products. This helped to retain UK production whilst } \\
\text { offshoring to China and it facilitated reshoring. }\end{array}$ \\
\hline & Global supply chain development & $\checkmark$ & $\checkmark$ & $\begin{array}{l}\text { Developing and maintaining a global supply network can } \\
\text { provide flexibility. For Cushion Co., this has allowed } \\
\text { them to support both their UK and China based production. }\end{array}$ \\
\hline
\end{tabular}

Kinkel 2014; Martínez-Mora and Merino 2014) and does not reflect joint venture agreements.

Fratocchi et al. (2014) argued reshoring will take place earlier and more rapidly for firms that have not built a factory offshore. Yet Cushion Co. has been able to grow and contract its offshore presence quickly despite previously owning a purpose-built factory. Once the reshoring process began, the company's Chinese premises were sold and it moved to a smaller rented factory. This transition was largely enabled by its retained UK staff, machinery, management, and systems. This adds to the existing literature (e.g. Gylling et al. 2015) by illustrating the advantages of maintaining production in a domestic location whilst offshoring. The UK base provided complementary capabilities, e.g. filling cushions made in China. In terms of the degree of reshoring, reshoring has not been undertaken in full - it has been thus far a partial reshoring process, allowing the company to obtain the benefits of being in China and in the UK. This dual location strategy 


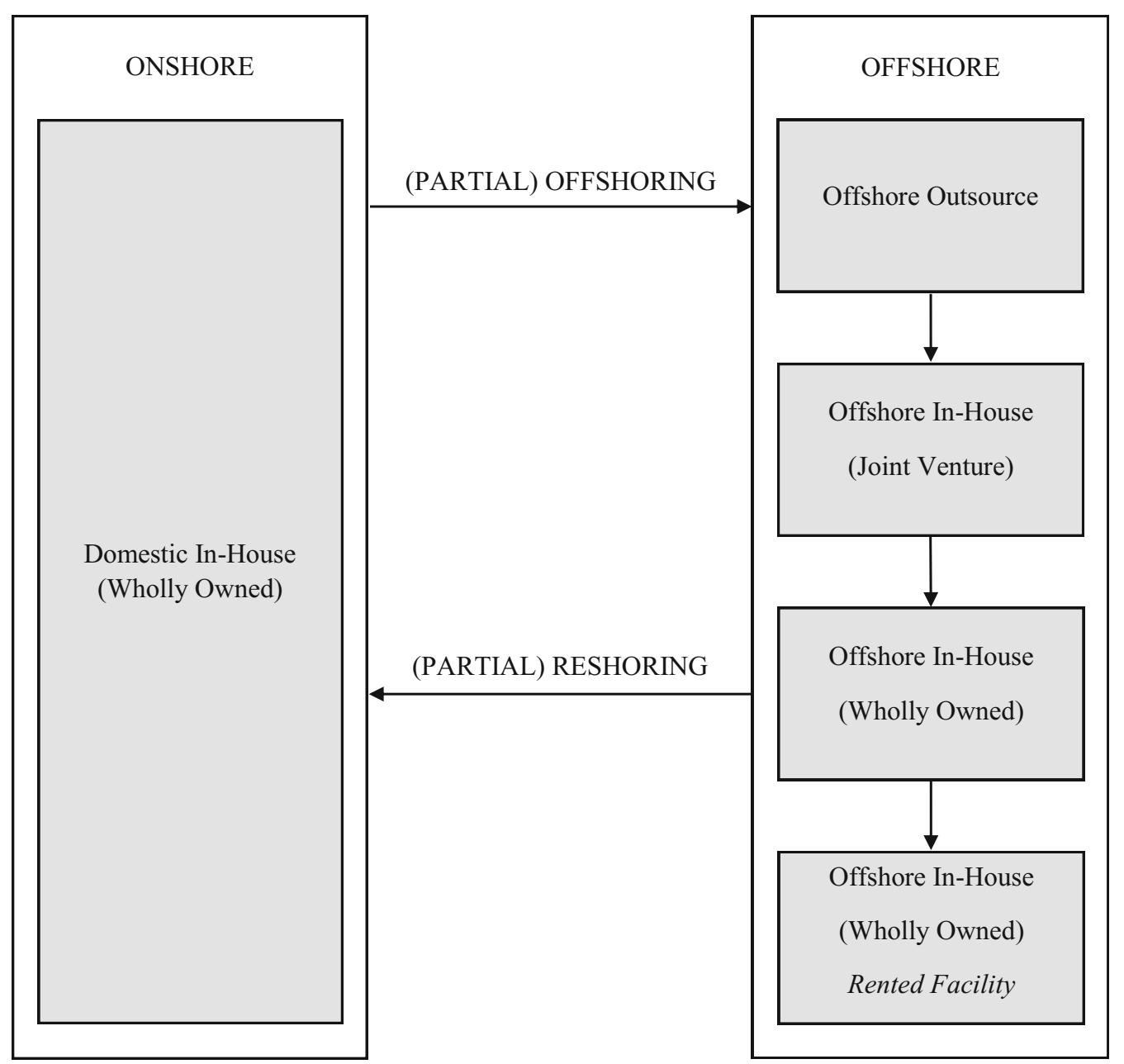

Fig. 3 The Relocation Process Trajectory of the Case Study Company (Cushion Co.)

may have similar advantages to a nearshoring approach (e.g. Ellram et al. 2013; Fratocchi et al. 2014), which refers to finding a location closer to home that achieves a compromise between the advantages of offshore (e.g. low wage economies) and onshore locations (e.g. speed to market and proximity to headquarters). A dual approach however also means resources can be shifted between locations to serve different markets and meet different customer requirements for speed, cost, quality, etc. Retaining a presence in China also reflects the changing role of the factory from cost-based to marketbased (e.g. serving Eastern markets). Similarly, MartínezMora and Merino (2014) noted how offshoring provides the opportunity to develop commercial ties with the local market.

An important aspect of operationalising the reshoring decision concerns timing, i.e. when to trigger the reversal process. Cushion Co. reached a tipping point for relocation whereby the drawbacks of being offshore began to add up. The cost differential between manufacturing in China vs. the UK became marginal; and without significant cost incentives, the advantages of increasing its domestic presence became difficult to ignore. This aspect - recognising when to take the reshoring decision - is a new factor for the framework.

Cushion Co.'s decision to relocate some of its production from China to the UK is the latest in a line of location decisions; and it cannot be understood without knowledge of the prior offshoring process. This is reflected in the 'swinging pendulum' concept used by Slepniov and Madsen (2015) to describe the continual movement between offshore and onshore.

The boundaries between the various location decisions are difficult to distinguish, as is evident from Fig. 3. This is because the process of implementation is, in Cushion Co., a gradual, incremental process. As outlined in the literature, location decisions are dynamic (Kinkel and Maloca 2009; Ellram et al. 2013; Gylling et al. 2015; Fratocchi et al. 2016). Indeed, the case provides empirical evidence of the dynamic nature of the process outlined by Mugurusi and de Boer (2013) demonstrating the reorganisation over time of its production network in terms of both location and governancel. Indeed, supporting Srai and Ané (2016), Cushion Co. is continually re-evaluating the needs of the business. When the environment changes again, e.g. wages rise in the UK or customers demand something else, the 
distribution of the firm's resources across its two locations will be revisited. Thus, the current trend is towards reshoring but this may change. It is a matter of finding the right location for a given activity at a given moment in time rather than of finding a way to bring everything back to a domestic location. This is akin to the notion of 'rightshoring' or 'intelli-sourcing' described by Tate (2014) and Fine (2013), respectively. The incremental nature of the implementation process is a further implementation factor identified from the case.

The case also provides an insight into how implementation barriers can be overcome. Although Cushion Co. retained a UK workforce, it must still face up to the skills shortage caused by offshoring (Bailey and De Propris 2014; Shih 2014). Supporting Shih (2014), the company is considering overcoming this by introducing in-house training. The case also highlights the importance of global supply chain development and maintaining a supplier network to serve multiple locations around the world. As a result, building strong relationships with suppliers and improving information sharing with suppliers is critical. In Cushion Co. this is done globally rather than locally, as advocated by Shih (2014). Local information sharing and relationship building is however important with customers and internal staff. It is also evident that strategic market movements have helped support Cushion Co.'s location decisions. For example, they moved up market by developing relationships with new UK customers that allowed them to maintain a continuous viable UK production presence.

\subsection{Contingency factors}

Nine of the eleven contingency factors are evident in the case, and they can now be categorised into those that are: company (and industry) related; product related; or behavioural (or individual) related (see Table 4). Five factors are considered company (and industry) related. In terms of the size of the firm, Cushion Co. is an SME that has quite rapidly offshored and reshored. This complements survey results from Kinkel (2012), although its decision was not motivated by an unwillingness to invest in offshore resources. The case also supports the relevance of ownership modes as a contingency factor. Its ownership of Chinese and UK production facilities explains the importance of many competitive priorities, which may be less influential when purely outsourcing. The changing ownership modes over time have also impacted the company's control and flexibility in both the decision making and implementation process. Capital intensiveness is also relevant. The textiles industry is generally characterised by low technology and high labour intensiveness, arguably making reshoring unattractive. Studies have shown that, despite this, reshoring can take place for specialised clothing (Ashby 2016) and luxury clothing (Robinson and Hsieh 2016). Cushions are an exception - they are simple to produce meaning the labour content is lower than for other textiles products. Supporting Stentoft et al. (2016a), industry related factors can influence reshoring but factors can also vary within an industry. Further, this case has highlighted that industry exceptions can occur. Government policy, e.g. reduced taxes and subsidies (Bailey and De Propris 2014; Pearce 2014; Tate et al. 2014), were not prominent in Cushion Co., suggesting they were either unavailable or ineffective. Cushion Co. had however previously received funding when establishing a UK factory, which was key to reshoring. Additionally, the company is considering using government support to introduce an apprenticeship scheme to address the skills gap. Bandwagon effects were not apparent as Cushion Co. were one of the first reshoring movers in the industry. This however may be an important factor in later reshoring waves, should they occur.

Four contingency factors are product related. The bulkiness of the product, e.g. its size and weight (Tate 2014), is relevant as cushions can be bulky to ship over long distances. This has impacted the reshoring decision and the use of the UK factory to fill empty cases. Market segments, as discussed by Martínez-Mora and Merino (2014), are also relevant. The company's strategic location decisions are underpinned by the markets it serves. Cushion Co. had established itself as a mass market producer but has moved up market, influencing its location decisions. Its Chinese factory helped to retain some price-sensitive customers and serve the Eastern market, with the company hitting different price points by utilising the strengths of its two locations. Customisation may be an important factor for design-led products requiring high levels of customer input; however, this was not a significant factor in this case. The company however benefits from close proximity to customers for coordination in the design process.

The two remaining contingency factors are behavioural. Management's perception of costs, i.e. prior misjudgements, was not apparent in the case. But the case does highlight the influence of emotional factors (Canham and Hamilton 2013; Fratocchi et al. 2016). Decision making power largely resides with Cushion Co.'s owner, a patriotic entrepreneur with an emotional attachment to the UK. This arguably triggered the decision to reshore sooner than it would have been triggered if the owner did not have an emotional attachment.

\subsection{Refined conceptual framework}

A refined version of the conceptual framework, enhanced using case study evidence, is presented in Fig. 4. Empirical evidence supports 20 of the original 29 drivers. All six original implementation considerations were relevant in Cushion Co. and a further four factors are added: 'tipping point for relocation', 'market movement', 'process of implementation - incremental vs. instantaneous' and 'global supply chain development'. In addition, the importance of information sharing and building strong relationships not only with suppliers but 
Table 4 Summary of Contingency Factors, Including Source of Case Evidence (if any)

\begin{tabular}{|c|c|c|c|c|}
\hline Category & Contingency Factor & $\begin{array}{l}\text { Primary } \\
\text { Evidence }\end{array}$ & $\begin{array}{l}\text { Secondary } \\
\text { Evidence }\end{array}$ & Explanation from the Case Study \\
\hline \multirow[t]{5}{*}{$\begin{array}{l}\text { Company (and industry) } \\
\text { related factors }\end{array}$} & Size of the firm & $\checkmark$ & $\checkmark$ & $\begin{array}{l}\text { The size of the firm can influence the importance given to the } \\
\text { reshoring drivers as well as when and how a firm reshores. } \\
\text { Cushion Co. provides an example of an SME that has } \\
\text { offshored and reshored production. Further, the process of } \\
\text { offshoring and reshoring was quite rapid. }\end{array}$ \\
\hline & Ownership modes & $\checkmark$ & & $\begin{array}{l}\text { Ownership can influence the importance given to the reshoring } \\
\text { drivers as well as when and how a firm reshores. Ownership } \\
\text { of UK and Chinese production facilities explains the } \\
\text { importance of many strategic asset seeking drivers for } \\
\text { Cushion Co. Further, changing ownership has influenced } \\
\text { location decisions in terms of control and flexibility }\end{array}$ \\
\hline & Government policy & $\checkmark$ & & $\begin{array}{l}\text { To improve the local (domestic) economy and facilitate } \\
\text { investment. Apprenticeship support to help overcome skills } \\
\text { shortage. Cushion Co are currently considering this option. }\end{array}$ \\
\hline & Capital intensiveness & $\checkmark$ & & $\begin{array}{l}\text { Capital intensiveness can influence the importance given to } \\
\text { reshoring drivers. Cushion Co. provides an example of a } \\
\text { firm within the labour-intensive textiles industry that has } \\
\text { reshored. Cushions however have a lower labour content } \\
\text { than many other products within the industry. }\end{array}$ \\
\hline & Bandwagon effects & & & $\begin{array}{l}\text { Not identified as a factor in this case (but suggested that this } \\
\text { could be relevant for those following Cushion Co.) }\end{array}$ \\
\hline \multirow[t]{4}{*}{ Product related factors } & $\begin{array}{l}\text { Market segments } \\
\quad \text { (e.g. product area) }\end{array}$ & $\checkmark$ & $\checkmark$ & $\begin{array}{l}\text { The market segment can influence the importance given to the } \\
\text { reshoring drivers as well as when and how a firm reshores. } \\
\text { Cushion Co., an established mass market producer, moved } \\
\text { up market to maintain UK production; offshoring to China } \\
\text { helped to retain lower cost customers; location decisions } \\
\text { are therefore underpinned by the markets served. }\end{array}$ \\
\hline & $\begin{array}{l}\text { Price points (e.g. low-range, } \\
\text { mid-range, etc.) }\end{array}$ & $\checkmark$ & $\checkmark$ & $\begin{array}{l}\text { Price points can influence the importance given to reshoring } \\
\text { drivers as well as determining how a firm reshores. For } \\
\text { Cushion Co., different price points can be achieved } \\
\text { depending on production location. Cushion Co. have } \\
\text { therefore ensured that flexibility has been built into their } \\
\text { reshoring decision making process. }\end{array}$ \\
\hline & $\begin{array}{l}\text { Bulkiness of the product } \\
\text { (size, weight, etc.) }\end{array}$ & $\checkmark$ & & $\begin{array}{l}\text { The bulkiness of the product can influence the importance } \\
\text { given to reshoring drivers as well as determining how a firm } \\
\text { reshores. Cushion Co. produces cushions that can be bulky to } \\
\text { ship over long distances, influencing decision making. Empty } \\
\text { cushion cases shipped from China for filling in the UK } \\
\text { allowed the company to keep its UK operation running. }\end{array}$ \\
\hline & Customised products & $\checkmark$ & & $\begin{array}{l}\text { Customised products can influence the importance given to } \\
\text { reshoring drivers as well as determining how a firm reshores } \\
\text { Although this is not identified as a major factor in this case, } \\
\text { the company benefits from close proximity to customers } \\
\text { for coordination in the design process. }\end{array}$ \\
\hline \multirow[t]{2}{*}{$\begin{array}{l}\text { Behavioural (or individual) } \\
\text { related factors }\end{array}$} & $\begin{array}{l}\text { Management perception } \\
\text { of cost }\end{array}$ & & & $\begin{array}{l}\text { Management's perception of cost can influence the importance } \\
\text { given to the reshoring drivers as well as when and how a } \\
\text { firm reshores This was not identified in the case - a lack of } \\
\text { planning or prior misjudgements did not influence the } \\
\text { reshoring process. }\end{array}$ \\
\hline & Emotional factors & $\checkmark$ & $\checkmark$ & $\begin{array}{l}\text { Emotional factors can influence the importance given to } \\
\text { reshoring drivers as well as determining how a firm reshores. } \\
\text { For Cushion Co., an emotional attachment to the UK appeared } \\
\text { to have impacted the attraction of maintaining a presence in } \\
\text { the UK and the perceived advantages of reshoring, such as } \\
\text { the social benefits. }\end{array}$ \\
\hline
\end{tabular}




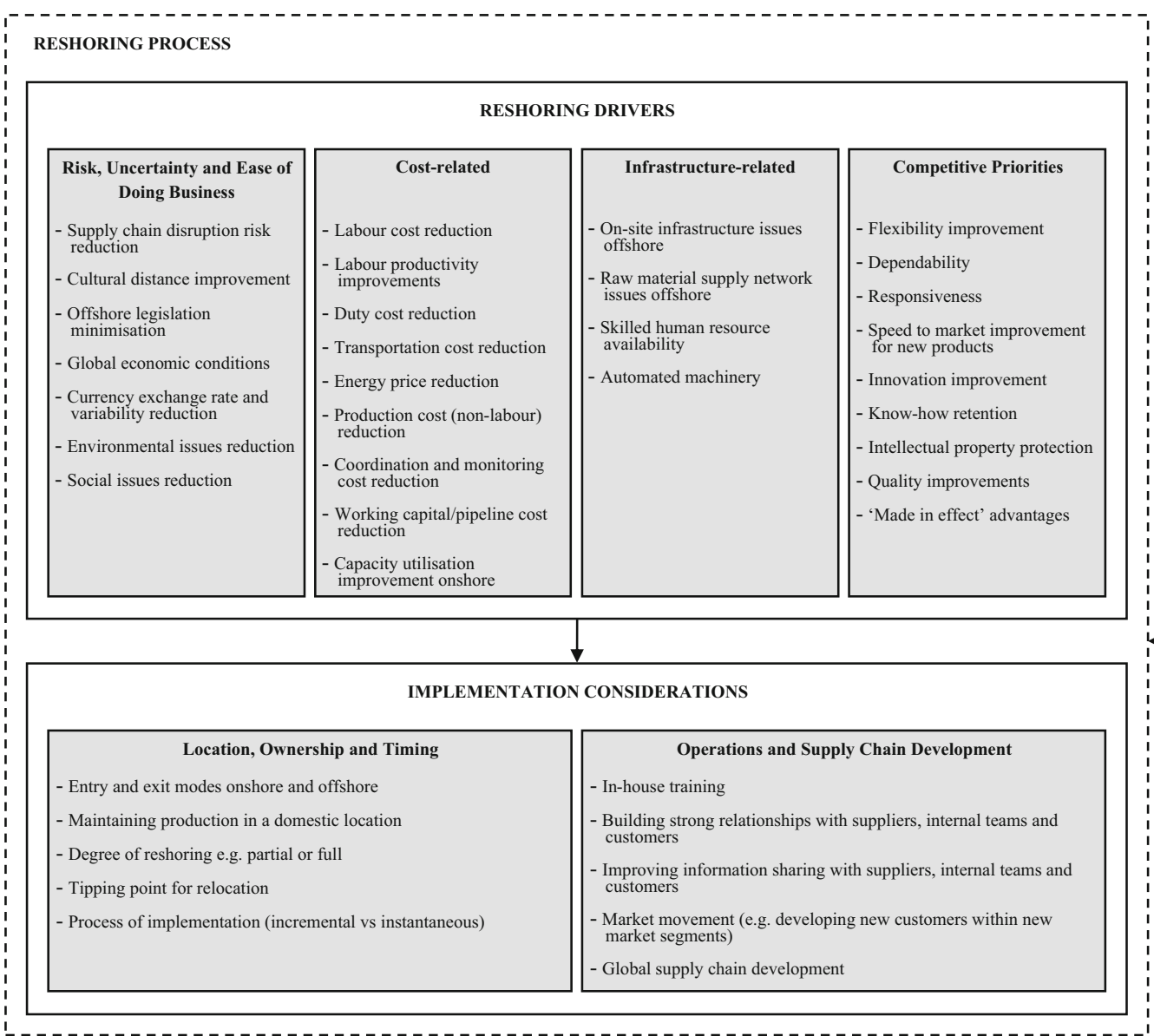

\begin{tabular}{|l|}
\multicolumn{1}{|c|}{$\begin{array}{c}\text { Company (and industry) } \\
\text { related }\end{array}$} \\
- Size of the firm \\
- Ownership modes \\
- Government policy \\
- Capital intensiveness \\
- Bandwagon effects
\end{tabular}
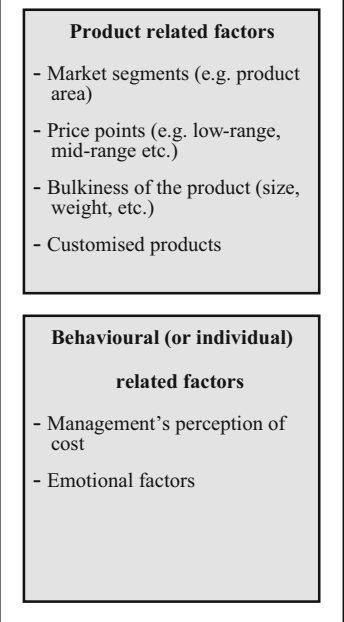

Fig. 4 Refined Conceptual Framework of the Reshoring Process using Case Study Evidence

also with internal teams and customers has been identified, with the existing factor therefore extended. The implementation factors have now been placed into two broad categories: 'location, ownership and timing' and 'operations and supply chain development' factors. Finally, no new contingency factors have been added but the case does support the relevance of adopting a contingency perspective, as was evident from Table 4. The existing contingency factors have now been split into those that are company (and industry) specific, product related, and behavioural (or individual) factors; and nine of the eleven factors were relevant in this case.

\section{Conclusions}

Reshoring is a current concern for both researchers and practitioners. While a body of literature on reshoring is emerging, much of the focus has been on why firms reshore. There has been a need to extend this work by investigating how the reshoring decision can be operationalised. Meanwhile, much of the literature is either conceptual or survey based. Although survey work is valuable, it tends to treat the reshoring phenomenon as a discrete event, e.g. examining the types of firms that have reshored and why they did so. There has also been a need to conduct more case study work to understand the unfolding process of reshoring, which allows for the process to be explored retrospectively whilst capturing future plans in more depth. The core purpose of this paper has therefore been to develop a conceptual framework of reshoring that draws on the extant literature and case study evidence. Cushion Co. represented an exemplar case of captive reshoring, allowing this complex decision, which is different to outsourcing, to be studied in its own right.

The paper has developed a contingency based conceptual framework of the reshoring paper by encompassing reshoring drivers, implementation considerations and contingency factors. A contingency-based perspective (Sousa and Voss 2008) has recently been advocated by Bals et al. (2016). To the best of our knowledge, this is the first framework to combine what is known about why and how firms reshore; and it is the first contingency-based approach to reshoring.

The initial conceptual framework has been refined based on case study evidence. The case provided evidence to support the relevance of 20 of the 29 drivers. It also supported the importance of the six implementation factors, supplemented the framework with a further four factors, and introduced two 
broad categories for categorising the implementation factors. The additions made to the framework in this area reflect the immature state of the reshoring literature on implementation and respond to recent calls for a more complete understanding of how firms can reshore (e.g. Fratocchi et al. 2014; Ancarani et al. 2015; Joubioux and Vanpoucke 2016; Srai and Ané 2016; Wiesmann et al. 2017). Finally, nine of the eleven contingency factors were relevant in the case study firm. No further contingency factors were identified, but the existing factors were split into: company (and industry), product, and behavioural (or individual) factors affecting the reshoring process. Further, the case has provided industry specific data (as encouraged by Stentoft et al. 2016a) to further understand the contingency perspective within the context of the textiles industry. The framework is argued to be more comprehensive than any other that can be found in the reshoring literature as it encompasses both reshoring drivers and implementation considerations whilst adopting a contingency perspective. Thus, it enlarges and complements past studies on offshoring and reshoring (e.g. Schoenherr et al. 2008; Ellram et al. 2013; Ancarani et al. 2015; Joubioux and Vanpoucke 2016).

A further contribution of the case is in providing a richer, more nuanced view of reshoring than can be found in much of the available literature. The case has demonstrated the importance of viewing the reshoring decision as part of a longer line of location decisions. Figure 3, as presented in Section 5.2, proposed an extension to the typology presented by Gray et al. (2013) to more accurately reflect the complexity and incremental nature of the onshore-offshore-reshore location and ownership decision. Supporting Mugurusi and de Boer (2013), reshoring can be considered a dynamic process, and the case provided empirical evidence demonstrating the reorganisation over time of its production network in terms of both location and governance. For Cushion Co., it was not a case of sending everything offshore and subsequently everything back. Instead, it has been a partial and incremental process, involving multiple changes of ownership and resulting in a dual location strategy that allows capacity utilisation and resources to be shifted between locations over time to meet the needs of different markets. The case has demonstrated the speed with which location decisions can be reversed and ownership modes changed. In this instance, despite captive offshoring and undergoing a large investment in extending their Chinese facilities in 2010, the reshoring process started two years later. Hence, the swinging pendulum concept as used by Slepniov and Madsen (2015). Further, the current trend is towards the Western domestic location, but this may change in the future; and retaining a presence on both sides of the globe provides the company with flexibility and the ability to quickly reverse its location decisions. It keeps its skilled workforce and supply chain active in both locations; and allows it to compete on various competitive priorities - cost, quality, speed, etc.

\subsection{Implications for practice and future research}

Reshoring may not be suitable for every company, product or process - as demonstrated by the contingencybased framework - but this paper should aid managers in deciding what to reshore and how to go about operationalising this decision successfully by proposing a structure for the reshoring decision. The case provides managers with an exemplar in terms of how an SME can compete globally and align its onshore/offshore location decisions with its capabilities and competitive priorities. It may be of particular interest to firms in the textiles industry and/or firms that have maintained a domestic production presence whilst offshoring. Further, it highlights the importance of skills embeddedness and the potential government assistance required to close skills gaps in countries that have experienced extensive offshoring.

The paper is based on a systematic review of the reshoring literature and a single case study. This approach has allowed for an in-depth approach and analysis. The scope of the literature review could however be extended, e.g. to the wider literature on global location decisions, and further case studies could be conducted, e.g. involving firms that are larger, in different industries (including services), in different countries, or that have reshored sourcing arrangements rather than captive production. This could help to identify additional factors currently missing from the framework or to further develop how the various factors are categorised. Future research could also assess the generality of our findings using a large-scale survey, which could also help to establish whether all of the contingency factors influence both the drivers and implementation, or if some influence only one part of the reshoring process. Furthermore, future research could assess how the drivers, governance modes and contingency factors differ when making offshoring versus reshoring decisions. This could help develop a framework that can assist managers throughout the continual movement between on and offshore locations. Longitudinal studies could also be particularly valuable for studying the reshoring phenomenon as it takes place. Meanwhile, behavioural studies could provide a new insight into the reversal of location misjudgements or how emotions and irrationality impact the location decision. Finally, the impact on reshoring of the UK's decision to leave the EU could be examined.

Acknowledgments This work was supported by the Economic and Social Research Council [grant number ES/J500094/1]

Open Access This article is distributed under the terms of the Creative Commons Attribution 4.0 International License (http:// creativecommons.org/licenses/by/4.0/), which permits unrestricted use, distribution, and reproduction in any medium, provided you give appropriate credit to the original author(s) and the source, provide a link to the Creative Commons license, and indicate if changes were made. 


\section{References}

Ancarani A, Di Mauro C, Fratocchi L, Orzes G, Sartor M (2015) Prior to reshoring: a duration analysis of foreign manufacturing ventures. Int J Prod Econ 169:141-155*

Arlbjørn JS, Mikkelsen OS (2014) Backshoring manufacturing: notes on an important but under-researched theme. J Purch Supply Manag 20(1):60-62*

Ashby A (2016) From global to local: reshoring for sustainability. Oper Manag Res, 9(3-4), pp.75-88.53:1-14*

Bailey D, De Propris L (2014) Manufacturing reshoring and its limits: the UK automotive case. Cambridge J Regions Econ Soc 7(3):379 $395^{*}$

Bals L, Kirchoff JF, Foerstl K (2016) Exploring the reshoring and insourcing decision making process: toward an agenda for future research. Oper Manag Res 9(3-4):102-116*

Barbieri P, Stentoft J (2016) Guest editorial: reshoring-a supply chain innovation perspective. Oper Manag Res, 9(3-4), pp.49-52

Bolisani E, Scarso E (1996) International manufacturing strategies: experiences from the clothing industry. Int J Oper Prod Manag 16(11): $71-84$

Bruce M, Daly L, Towers N (2004) Lean or agile: a solution for supply chain management in the textiles and clothing industry? Int J Oper Prod Manag 24(2):151-170

Canham S, Hamilton RT (2013) SME internationalisation: offshoring, "backshoring", or staying at home in New Zealand. Strategic Outsourcing: An International Journal 6(3):277-291

Caniato F, Elia S, Luzzini D, Piscitello L, Ronchi S (2015) Location drivers, governance model and performance in service offshoring. Int J Prod Econ 163:189-199

Dachs B, Kinkel S (2013) Back-shoring of production activities in European manufacturing: evidence from a large scale survey, paper presented at the EURopean operations management association (EurOMA) conference. Dublin, Ireland, 7-12 June*

Dana LP, Hamilton RT, Pauwels B (2007) Evaluating offshore and domestic production in the apparel industry: the small firm's perspective. J Int Entrep 5(3-4):47-63

Denyer D, Tranfield D (2009) Producing a systematic review. In: Buchanan D, Bryman A (eds) The Sage handbook of organizational research methods. Sage Publications Ltd, Thousand Oaks, pp 671689

Eisenhardt KM (1989) Building theories from case study research. Acad Manag Rev 14(4):532-550

Ellram L, Tate WL, Peterson KJ (2013) Offshoring and reshoring: an update on the manufacturing location decision. J Supply Chain Manag 49(2):14-21*

Fine C (2013) Intelli-sourcing to replace offshoring as supply chain transparency increases. J Supply Chain Manag 49(2):6-7*

Foerstl K, Kirchoff JF, Bals L (2016) Reshoring and insourcing: drivers and future research directions. Int J Phys Distrib Logist Manag 46(5):492-515*

Fratocchi L, Mauro CD, Barbieri P, Nassimbeni G, Zanoni A (2014) When manufacturing moves back: concepts and questions. J Purch Supply Manag 20(1):54-59*

Fratocchi L, Ancarani A, Barbieri P, Di Mauro C, Nassimbeni G, Sartor M, Vignoli M, Zanoni A (2016) Motivations of manufacturing reshoring: an interpretative framework. Int J Phys Distrib Logist Manag 46(2):98-127*

Grappi S, Romani S, Bagozzi RP (2015) Consumer stakeholder responses to reshoring strategies. J Acad Mark Sci 43(4):453-471*

Gray J, Skowronski K, Esenduran G, Rungtusantham MJ (2013) The reshoring phenomenon: what supply chain academics ought to know and should do. J Supply Chain Manag 49(2):27-33*
Gylling M, Heikkilä J, Jussila K, Saarinen M (2015) Making decisions on offshore outsourcing and backshoring: a case study in the bicycle industry. Int J Prod Econ 162:92-100*

Hartman PL, Hartman PL, Ogden JA, Ogden JA, Hazen BT, Hazen BT (2017) Bring it back? An examination of the insourcing decision. Int J Phys Distrib Logist Manag 47(2/3):198-221*

Holweg M, Reichhart A, Hong E (2011) On risk and cost in global sourcing. Int J Prod Econ 131(1):333-341

Huq F, Pawar KS, Rogers H (2016) Supply chain configuration conundrum: how does the pharmaceutical industry mitigate disturbance factors? Prod Plan Control 27(14):1206-1220*

Jahns C, Hartmann E, Bals L (2006) Offshoring: dimensions and diffusion of a new business concept. J Purch Supply Manag 12(4):218 231

Joubioux C, Vanpoucke E (2016) Towards right-shoring: a framework for off-and re-shoring decision making. Oper Manag Res 9(3-4):117$132 *$

Kedia BL, Mukherjee D (2009) Understanding offshoring: a research framework based on disintegration, location and externalization advantages. J World Bus 44(3):250-261

Kinkel S (2012) Trends in production relocation and backshoring activities: changing patterns in the course of the global economic crisis. Int J Oper Prod Manag 32(6):696-720*

Kinkel S (2014) Future and impact of backshoring - some conclusions from 15 years of research on German practices. J Purch Supply Manag 20(1):63-65*

Kinkel S, Maloca S (2009) Drivers and antecedents of manufacturing offshoring and backshoring - a German perspective. J Purch Supply Manag 15(3):154-165*

Kinkel S, Zanker C (2013) New patterns of German production relocation and back shoring activities after the global economic crisis. EurOMA-EURopean Operations Management Association Conference. Dublin, Ireland, p 7-12*

Kinkel S, Lay G, Maloca S (2007) Development, motives and employment effects of manufacturing offshoring of German SMEs. Int J Entrepren Small Bus 4(3):256-276*

Leibl P, Morefield R, Pfeiffer R (2010) A study of the effects of backshoring on the EU, American Society of Business and Behavioral Sciences, proceedings of the 13th international conference, pp 72-79*

Martínez-Mora C, Merino F (2014) Offshoring in the Spanish footwear industry: a return journey? J Purch Supply Manag 20(4):225-237*

McCutcheon DM, Meredith JR (1993) Conducting case study research in operations management. J Oper Manag 11(3):239-256

McIvor R (2013) Understanding the manufacturing location decision: the case for the transaction cost and capability perspectives. J Supply Chain Manag 49(2):23-25*

Moradlou H, Backhouse CJ, Ranganathan R (2017) Responsiveness, the primary reason behind re-shoring manufacturing activities to the UK: an Indian industry perspective. Int J Phys Distrib Logist 47(2/3):222-236*

Mugurusi G, de Boer L (2013) What follows after the decision to offshore production? A systematic review of the literature. Strategic Outsourcing: An International Journal 6(3):213-257

Mukherjee D, Gaur AS, Datta A (2013) Creating value through offshore outsourcing: an integrative framework. J Int Manag 19(4):377-389

Patrucco AS, Scalera VG, Luzzini D (2016) Risks and governance modes in offshoring decisions: linking supply chain management and international business perspectives. Supply Chain Forum: an International Journal 17(3):170-182

Pearce JA (2014) Why domestic outsourcing is leading America's reemergence in global manufacturing. Bus Horiz 57(1):27-36*

Platts KW, Song N (2010) Overseas sourcing decisions-the total cost of sourcing from China. Supply Chain Management: An International Journal 15(4):320-331 
Presley A, Meade L, Sarkis J (2016) A strategic sourcing evaluation methodology for reshoring decisions. Supply Chain Forum: An International Journal 17(3):156-169*

Quintens L, Pauwels P, Matthyssens P (2006) Global purchasing: state of the art and research directions. J Purch Supply Manag 12(4):170181

Robinson PK, Hsieh L (2016) Reshoring: a strategic renewal of luxury clothing supply chains. Oper Manag Res 9(3-4):89-101*

Roza M, Van den Bosch FA, Volberda HW (2011) Offshoring strategy: motives, functions, locations, and governance modes of small, medium-sized and large firms. Int Bus Rev 20(3):314-323

Schoenherr T, Tummala VR, Harrison TP (2008) Assessing supply chain risks with the analytic hierarchy process: providing decision support for the offshoring decision by a US manufacturing company. J Purch Supply Manag 14(2):100-111

Shih WC (2014) What it takes to reshore manufacturing successfully. MIT Sloan Manag Rev 56(1):55*

Simchi-Levi D, Peruvankal JP, Mulani N, Read B, Ferreira J (2012) Is it time to rethink your manufacturing strategy? MIT Sloan Manag Rev 53(2):20*

Slepniov D, Madsen ES (2015) From offshoring to Backshoring: the path of two Danish companies and implications in the next era of Chinese manufacturing. In: The Eleventh International Symposium on Global Manufacturing and China

Sousa R, Voss CA (2008) Contingency research in operations management practices. J Oper Manag 26(6):697-713

Spina G, Caniato F, Luzzini D, Ronchi S (2013) Past, present and future trends of purchasing and supply management: an extensive literature review. Ind Mark Manag 42(8):1202-1212

Srai JS, Ané C (2016) Institutional and strategic operations perspectives on manufacturing reshoring. Int J Prod Res 54(23):7193-7211*

Stentoft J, Mikkelsen OS, Jensen JK (2016a) Offshoring and backshoring manufacturing from a supply chain innovation perspective. Supply Chain Forum: An International Journal, 17(4):190-204*

Stentoft J, Olhager J, Heikkilä J, Thoms L (2016b) Manufacturing backshoring: a systematic literature review. Oper Manag Res 9(34):53-61*
Stentoft J, Mikkelsen OS, Jensen JK (2016c) Flexicurity and relocation of manufacturing. Oper Manag Res 9(3-4):133-144*

Tate WL (2014) Offshoring and reshoring: U.S. insights and research challenges. J Purch Supply Manag 20(1):66-68*

Tate WL, Bals L (2017) Outsourcing/offshoring insights: going beyond reshoring to rightshoring. Int J Phys Distrib Logist Manag 47(2/3): 106-113*

Tate WL, Ellram LM, Schoenherr T, Petersen KJ (2014) Global competitive conditions driving the manufacturing location decision. Bus Horiz 57(3):381-390*

Teng SG, Jaramillo H (2006) Integrating the US textile and apparel supply chain with small companies in South America. Supply Chain Management: An International Journal 11(1):44-55

Tranfield D, Denyer D, Smart P (2003) Towards a methodology for developing evidence-informed management knowledge by means of systematic review. Br J Manag 14(3):207-222

Uluskan M, Joines JA, Godfrey AB (2016) Comprehensive insight into supplier quality and the impact of quality strategies of suppliers on outsourcing decisions. Supply Chain Management: An International Journal 21(1):92-102*

Voss C, Johnson M, Godsell J (2016) Case research in Research Methods for Operations Management. In: Karlsson C (ed). Routledge, London, pp 165-197

Wiesmann B, Snoei JR, Hilletofth P, Eriksson D (2017) Drivers and barriers to reshoring: a literature review on offshoring in reverse. Eur Bus Rev 29(1):15-42*

Wu X, Zhang F (2014) Home or overseas? An analysis of sourcing strategies under competition. Manag Sci 60(5):1223-1240*

Yin RK (2009) Case study research, 4th edn. Beverly Hills, Sage

Zhai W, Sun S, Zhang G (2016) Reshoring of American manufacturing companies from China. Oper Manag Res 9(3-4):62-74*

Zorzini M, Stevenson M, Hendry LC (2014) Coordinating offshored operations in emerging economies: a contingency-based study. Int J Prod Econ 153:323-339

Zorzini M, Hendry LC, Huq FA, Stevenson M (2015) Socially responsible sourcing: reviewing the literature and its use of theory. Int J Oper Prod Manag 35(1):60-109 